\title{
NEO-ARAMAIC GARSHUNI: OBSERVATIONS BASED ON MANUSCRIPTS
}

\author{
EMANUELA BRAIDA \\ UNIVERSITY OF TORONTO*
}

\begin{abstract}
The present paper is a preliminary study of key spelling features detected in the rendering of foreign words in some Neo-Aramaic Christian texts belonging to the late literary production from the region of Alqosh in Northern Iraq. This Neo-Syriac literature laid the groundwork for its written form as early as the end of the $16^{\text {th }}$ century, when scribes of the so-called 'school of Alqosh' wrote down texts for the local population. From a linguistic point of view, scribes and authors developed a Neo-Syriac literary koine based on the vernacular languages of the region of Alqosh.

Despite the sporadic presence of certain orthographical conventions, largely influenced by Classical Syriac, these texts lacked a standard orthography and strict conventions in spelling. Since a large number of vernacular terms have strayed over time from the classical language or, in many cases, they have been borrowed from other languages, the rendering of the terms was usually characterized by a mostly phonetic rendition, especially in the case of foreign words that cannot be written according to an original or a standard form. In these cases, scribes and authors had to adapt the Syriac alphabet to
\end{abstract}

* A Post Doctoral Research Fellowship granted by Foreign Affairs and International Trade Canada. I would like to thank my supervisor, Prof. Amir Harrak, for the guidance, encouragement and advice he has provided throughout my time as Post-doctoral fellow. 
the phonetic representation of an Arabic, Persian, Turkish, Kurdish or maybe Western term. The results are hardly normalizable, since the graphic rendering of the terms often reflects the phonetic characteristics of a particular vernacular.

This complicated linguistic situation is well reflected in the Neo-Aramaic version of the Story of Abiqar preserved MS London Sachau 9321, where a large amount of loanwords from a number of non-Aramaic languages shows a lively regional vocabulary to which the Neo-Aramaic dialects actively contributed.

The present paper is a preliminary study of key spelling features detected in the rendering of foreign words in some Neo-Aramaic Christian texts. These texts belong to the late literary production deriving from the region of Alqosh in Northern Iraq. ${ }^{1}$ Literary production in this region has a long tradition in manuscript form, unlike the area of Lake Urmia in Northwestern Iran. In the region of Urmia, the development of Christian literary production began in the 1830s, when British and American Protestant missionaries introduced the use of the press schools as practical remedies against widespread illiteracy. Linguistically speaking, they normalized the Aramaic dialect of Urmia, giving it a standard form called sureth. As E. Odisho pointed out, "the choice fell on the Urmi dialect not because it was widely spread or accepted by other inhabitants or other regions and villages or because it maintained greater affinity to the old written languages. The choice was merely because the

${ }^{1}$ The manuscripts on which this study is mainly based have been edited in the following texts: Emanuela Braida, "A Story of Ahiqar in Neo-Aramaic according to MS London Sachau 9321," Journal of the Canadian Society for Syriac Studies 14 (2014), forthcoming; Emanuela, Braida, "A Hagiographical Tale: On the Hermit Barmalka by Joseph 'Abbaya of Alqosh", in Religious Poetry in Vernacular Syriac from Northern Iraq (17th-20th Centuries). An Anthology, Corpus Scriptorum Christianorum Orientalium 627 and 628, ed. A. Mengozzi (Leuven: Peeters, 2011), I, 95-108; II, 83-98; Emanuela, Braida, "A Poetic Adaptation of Historical Sources: On an Attack by the Mongols at Karamlish by Thomas Hanna of Karamlish", in Religious Poetry in Vernacular Syriac from Northern Iraq (17th-20th Centuries). An Anthology, Corpus Scriptorum Christianorum Orientalium 627 and 628, ed.

A. Mengozzi (Leuven: Peeters, 2011), I, 109-31; II, 99-119. 
missionaries happened to have most of their main headquarters there."2 This new literary language was written in the traditional Syriac alphabet and was not a replica of the Urmi dialect, since it mostly followed the classic models of historical and etymological spelling rather than the spoken language. Furthermore, a number of elements of other spoken dialects and many of the Arabic, Persian, Turkish and Kurdish loanwords which were already common in the everyday language were brought in. From the mid-nineteenth century several magazines were printed in the Urmia area that grew to become an example to follow for many subsequent publishing initiatives of Neo-Aramaic speakers in the diaspora. From this newly established standard written language, a spoken koine arose and became a widespread 'lingua franca' among the Assyrian speakers after the World War I. ${ }^{3}$

As for the Christian Neo-Syriac literature of Northern Iraq, it laid the groundwork for its written form as early as the end of the $16^{\text {th }}$ century. In the region of Mosul, scribes of the so-called 'school of Alqosh' wrote down texts assiduously, translating biblical texts and transcribing - and sometimes also composing - poems for the local population. From a linguistic point of view, scribes and authors developed a Neo-Syriac literary koine based on the vernacular languages of the region of Alqosh. Most of their works consisted of long religious poems called durekyatha. There are also examples of very different kinds of compositions, including historical poems, folk songs, and lullabies, although these genres are represented only in $19^{\text {th }}$ century manuscripts. ${ }^{4}$

All the neo-Aramaic manuscripts coming from the Northern Iraq area were written in the traditional East-Syriac alphabet.

${ }^{2}$ Edward Odisho, The Sound System of Modern Assyrian (Wiesbaden: Harrassowitz, 1988), 19.

${ }^{3}$ For a comprehensive overview of this literature, see Hendrika L. Murre-van den Berg, From a Spoken to a Written Language: The Introduction and Development of Literary Urmia Aramaic in the Nineteenth Century (Leiden: Publication of the De Goeje Fund, 1999).

${ }^{4}$ For an introduction into this literature, see Rudolf Macuch, Geschichte der spät- und neusyrischen Literatur (Berlin: Gruyter, 1976); Fabrizio A. Pennacchietti, Il Ladrone e il Cherubino: Dramma Liturgico Cristiano Orientale in Siriaco e Neoaramaico (Torino: Silvio Zamorani Editore, 1993); and Alessandro Mengozzi, Israel of Alqosh and Joseph of Telkepe: A Story in a Truthful Language (Leuven: Peeters, 2002). 
Despite the sporadic presence of certain orthographical conventions, largely influenced by Classical Syriac, these texts lacked a standard orthography and strict conventions in spelling. However, when a Neo-Aramaic scribe could draw inspiration from his own cultural background, he showed that Classical Syriac was the basis of his literary choices, even if this language was far removed from his everyday use. Some historical spelling variants are very common in manuscripts of any period and testify the lasting use of words in classical Syriac. This is the case, for example, of the historical spelling (and probably pronunciation) of terms and names directly related to the religious tradition, as mshiha, 'Christ', or 'edta, 'church', that usually retain heth and 'ayn contrary to the phonetic tendency in spelling / b / with kap and / / with alef, which led to phonetic spellings such as khelma, 'dream', and 'ayna, 'eye'.

However, a large number of vernacular terms have strayed over time from the classical language or, in many cases, they have been borrowed from other languages, since the multilingualism represents the common linguistic context of the neo-Aramaic speaking communities. As the manuscript tradition of Alqosh represents the written record of an oral culture, the exact rendition of a term - regardless of its historical form - is often important for literary purpose (metric, rhyme) and proper understanding of the text by an audience. For these reasons, the rendering of the terms is usually characterized by a mostly phonetic rendition, especially in the case of foreign words that cannot be written according to an original or a standard form.

Since the so-called Iraqi Kurdistan is a border region, the influence of neighboring languages is very strong and evident in the pronunciation, loanwords, and sometimes even the grammar of Neo-Aramaic languages. The region in question borders Iran to the East, Turkey to the North, Iraq to the West and to the South, a fact which explains why a number of Arabic, Persian, Kurdish and Turkish terms are common in all the neo-Aramaic languages. Furthermore, the position of Neo-Aramaic speaking communities among Islamic majorities exposed them to a high number of linguistic entries in relation to the cultural prestige of Islamic languages as Arabic or Persian.

In the case of foreign words a scribe cannot resort to etymological forms and historical renderings, but he must adapt his alphabet to the phonetic representation of a term. This procedure 
must adapt the Syriac alphabet to the phonetic representation of an Arabic, Persian, Turkish, Kurdish or maybe Western term. The results are hardly normalizable, since they depend on many different factors. Usually the more an author is learned, the more his transcriptions follow consistent rules, but it is also usual that a learned author tends to limit the use of foreign loanwords in favor of Aramaic synonyms, even if they are sometimes obsolete. By contrast, a less educated scribe tends to use ordinary words even though not Aramaic, transcribing them in an arbitrary way. The little or no knowledge of the spelling of the word in its original language is often evident in the variety of transcripts that may appear within a single text.

For representing phonemes extra to the original Aramaic phonologic system, the modern texts show a number of diacritics in addition to the traditional vocalization based on the system of vowel points. The most common occurrences in rendering foreign consonants are listed in the following table.

\begin{tabular}{|c|c|c|c|c|c|}
\hline & $\begin{array}{c}\text { Neo- } \\
\text { Aramaic/ } \\
\text { Syriac }\end{array}$ & Arabic & Persian & Kurdish & Turkish \\
\hline , & 2 & $1 \varepsilon$ & 1 & 1 & 1 \\
\hline $\mathrm{b} / \mathrm{v}$ & ب/ ت & ס ب & ب ب و & ب ب ث & ب ب و \\
\hline $\mathrm{g} / \mathrm{j} / \mathrm{gh}$ & ה & Ø $\quad \dot{\varepsilon}$ & $\dot{\varepsilon} \quad$ گ & $\dot{\varepsilon} \quad$ گ & $\dot{\varepsilon} \quad$ گ \\
\hline $\mathrm{d} / \mathrm{d}$ & $\stackrel{?}{?}$ & ذ ذ & ذ & د & ذ ذ \\
\hline $\mathrm{h}$ & न & $ه$ & $ه$ & ه & ه \\
\hline $\mathrm{w} / \mathrm{b}$ & 。 & و & 9 & 9 & 9 \\
\hline z & , & j & j & j j & j j \\
\hline $\mathrm{h} / \mathrm{x}$ & מـ & $\dot{\tau} \quad \tau$ & $\dot{\tau}$ & $\dot{\tau}$ & $\dot{\tau}$ \\
\hline ț/ & $+/ 8$ & ض ظ ط & $\varnothing$ & $\varnothing$ & $\varnothing$ \\
\hline y & 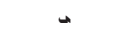 & ي & ى & ى & ى \\
\hline $\mathrm{k} / \mathrm{x} / \operatorname{ch}(\mathrm{c})$ & $5 / 5 / 55$ & 5) & ت & ت & ت \\
\hline 1 & $s$ & J & J & J & J \\
\hline $\mathrm{m}$ & 7 & 5 & 5 & 5 & 5 \\
\hline $\mathrm{n}$ & a & ن & ن & ن & ن ن \\
\hline $\mathrm{s}$ & ص & س & س س & س س & س \\
\hline$e^{\circ}$ & دا & $\varepsilon$ & $\varnothing$ & $\varnothing$ & $\varnothing$ \\
\hline
\end{tabular}




\begin{tabular}{|c|c|c|c|c|c|}
\hline & $\begin{array}{c}\text { Neo- } \\
\text { Aramaic/ } \\
\text { Syriac }\end{array}$ & Arabic & Persian & Kurdish & Turkish \\
\hline $\mathrm{p} / \mathrm{f}$ & $s / \dot{s}$ & ف ס & ب & ب ֶ ف & ب \\
\hline $\mathrm{s} / \mathrm{d} /$ & $5 / 5$ & ظ ض ص & $\varnothing$ & $\varnothing$ & $\varnothing$ \\
\hline q & טد & ق & ق & ق & ق \\
\hline $\mathrm{r}$ & j & J & J & ر ر & J \\
\hline sh & $x$ & ش & ش & ش & ش \\
\hline$t / \underline{t}$ & A & $\ddot{H}$ & ت & ت & ت \\
\hline
\end{tabular}

The merging of alap $/ \%$ and 'ayn / $/$ is frequent in the case of both Syriac words and Arabic loanwords, where alap usually

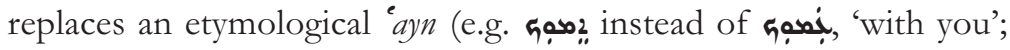

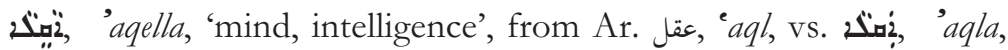

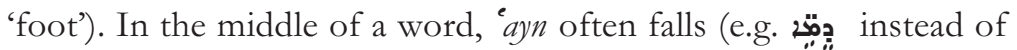

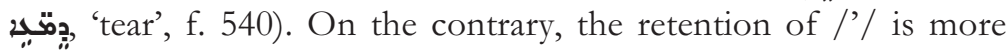
common than the phonetic spelling / / with terms directly related

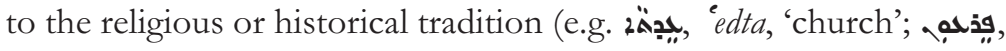
'Pharaoh') and in the case of less usual words (e.g. מُبحقدة, 'craftsman', from Pers. صنعت گر).

The letters begadkepat are often marked by a dot above the consonant $(q \bar{u} \bar{s} s \bar{a} y \bar{a})$ in the case of hard pronunciation and by a dot below the consonant (rükkajkha) in the case of spirantized allophone. This was not a common practice in Syriac, where the allophones of the begadkepat were established by precise phonological rules. Since the spirantization is no longer deduced from the syllabic pattern in Neo-Aramaic, it has to be noted in modern texts with greater consistency than in Classical Syriac. In fact, the Neo-Aramaic letters begadkepat rarely alternate their hard and spirantized allophones according to the rules of the Syriac phonology, but usually remain hard or spirantized in all forms of their stem pattern depending on their hard or spirantized aspect in the active participle. ${ }^{5}$ Moreover, the loanwords cannot fall under the rules of the Semitic phonology and their pronunciation needs to be reported unambiguously.

In the case of beth preceded by a vowel, both plosive and spirantized pronunciations are often marked (e.g. ביביה: 'sacrifices';

\footnotetext{
${ }^{5}$ Murre-van den Berg, From a Spoken, 140.
} 
, حبنس , from Ar. 'prison'). However, the spirantized allophone $/ \mathrm{v} /$ is an uncommon sound in Neo-Aramaic and many modern Eastern dialects often leave /b/ unfricativized - and then unmarked

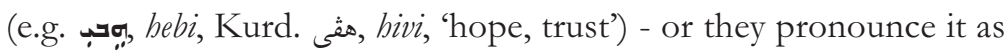

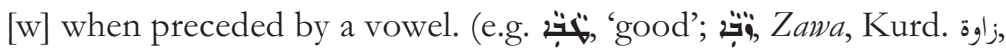

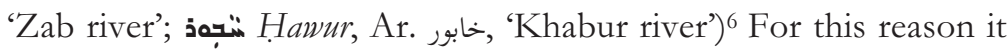
frequently occurs the graphic merging of /v/ $\mathbf{y}$ and /w/ o, where the grapheme /v/ usually represents the historical spelling of the word (e.g. دо2,' 'awed instead of ï, 'aved, 'to do').

Pers. and Turk. vav, on the contrary, is usually transcribed as

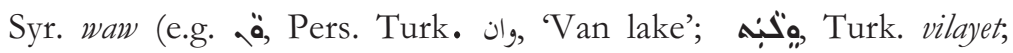

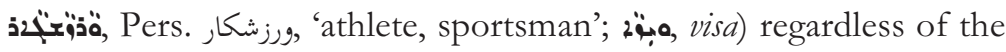
sound. The spelling apparently plays a more important role than phonetics in a number of cases, probably because they are more related to a written context than a vernacular practice.

In the case of diphthongs av and aw, they are usually

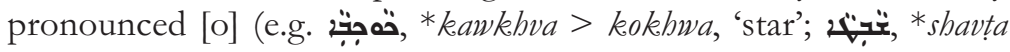
$>$ shota, 'tribe'). Sometimes they are spelled accordingly, particularly in case of everyday terms (e.g. gora, 'man, husband').

Highly characteristic in Eastern printed texts - but not in manuscripts - is the combination zqapa $+p e$ ' with a little semicircle under the letter which acts as a diphthong and pronounced [o] (e.g. , nafsha $>$ * nawsha $>$ nosha, 'soul, self'). ${ }^{7}$

The diacritic punctuation often employed to mark the

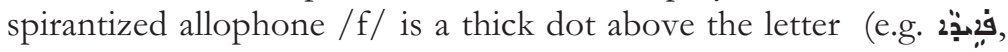

${ }^{6}$ Odisho noticed: "The alphabet character waw or the 'spirantized' is essentially realized in the Koine as a labio-palatal approximant [] identical to the initial sound in the French word "huit". It changes into a labio-velar approximant $[\mathrm{w}]$, as in the French name "Louis" or the English pronoun "we" when it occurs in emphatic contexts or before back vowels." (Odisho, The Sound System, 26).

7 The form nawsha, hence nosha has been known as customary East-Syriac pronunciation of the classical word nafsa since Barhebraeus. Th. Nöldeke, Grammatik der neusyrischen Sprache am Urmia-See und in Kurdistan (Leipzig: T.O. Weigel, 1868), p. 50; R. Duval, Traité de grammaire syriaque (Paris: F. Vieweg, 1881), pp. 29-30. I would thank Alessandro Mengozzi for this suggestion. 
from Ar. فائدة, 'advantage, interest'; فيده, 'he passed', from the Ar.

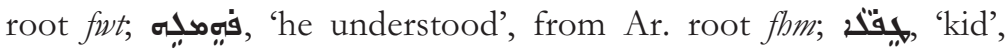
from Ar. طفل (b). 'Obviously pe' without distinctive marks is used to

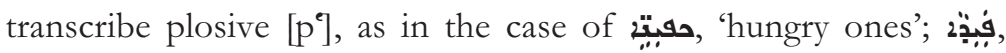

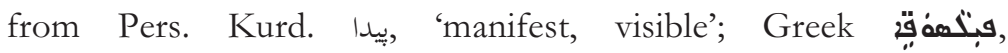
'philosophers'. Since most modern Eastern dialects follow the practices of Syriac, they often leave an original / f / plosive and then

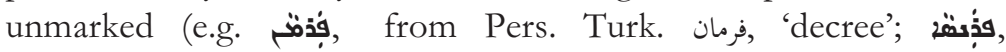
'France'). ${ }^{9}$

Gamal without distinctive marks can transliterate the Pers. Kurd. Turk. voiced, unaspirated, velar plosive gāf $\}$ [g] (e.g.

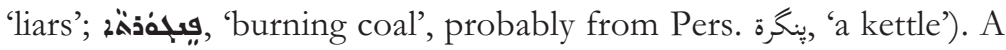

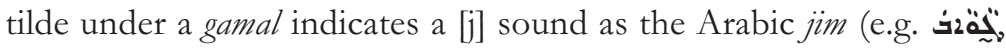

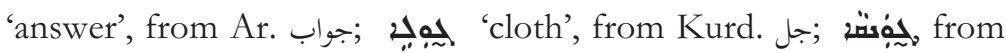
Kurd. جوانقه, 'youth, young man'). A dot below - sometimes even inside - a gamal is used for writing Arabic ghayn (e.g. بحته “mistake',

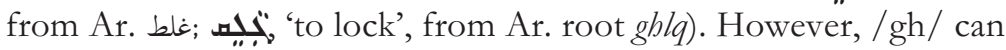

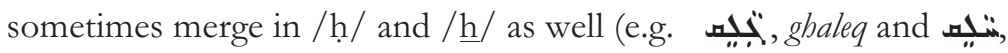
xâleq, 'to create', from Ar. root $\underline{b}(q)$.

The voiceless, palato-alveolar affricate /ch/ [t $\left.\int\right]$ as Pers. Kurd. Turk. che $\mathrm{F}$ is sometimes represented by a kap with three dots under the letter, particularly in printed texts (e.g. يُخَّة, parcha, Kurd. p'erçe, 'small piece'), while in many manuscripts it is common to

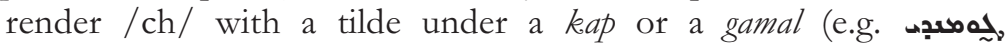
chumendi, 'nothing', composed by Kurd. ç, 'none, not any' and Aram. מعeي, 'thing').

In the case of words of Syriac origins, the merging of $/ \underline{k} /$ (spelled as a kap with a dot below) and the Syriac etymological heth often occurs so as to reflect the voiceless, pharyngal fricative /h/

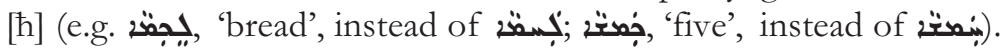

${ }^{8}$ Alessandro Mengozzi and Mustafa Dehqan, "A Kurdish Garshuni Poem by David of Barazne (19th Century)," Hugoye: Journal of Syriac Studies 17:1 (2014): 64, see footnote 26.

${ }^{9}$ In addition, since Old Aramaic /f/ was sometimes spelled as plosive $<\mathrm{b}>$ (e.g. nefesh $>$ nebesh vs. nafsha $>$ nawsha), we can assume a further merging $/ \mathrm{f} />/ \mathrm{b} />/ \mathrm{v} />/ \mathrm{w} /$. 
A sporadic merging between / $/ \mathrm{k} /$ and $/ \mathrm{gh} /$ could be noted as in the case of iُّة, from Pers. 'Agha'. On a few occasions, a merging can also be noted between $/ \mathrm{h} /$ and the voiceless, glottal fricative $h a$ '

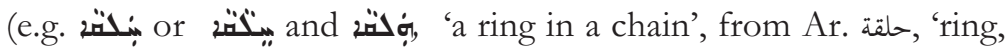
circle').

In the case of Arabic loanwords, kap with a dot can replace an etymological ha' (e.g. فمبه: frequently, a $\underline{b} a$ ' (e.g. يليس, 'nature', from Ar. خلق). The frequent merging of $/ \mathrm{k} /, / \mathrm{h} /$ and $/ \underline{h} /$ bears obvious witness to a common fricative pronunciation $[\mathrm{x}]$ of the three letters.

A merging between $/ \mathrm{h} /, / \mathrm{h} /$ and the voiceless, uvular plosive

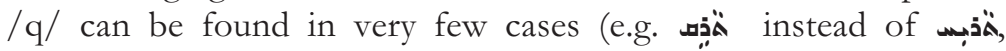
'history, account', from Ar. تاريخ), although this inconsistency seems likely to be an individual preference. ${ }^{10}$

A sporadic inconsistency between /s/ and / $\mathrm{z} /$ is noted, as in the case of instead of the month of Tammuz.

In few cases /ṣ/ can merge with /s/, as in تقفه 'cage', from Ar.

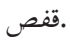

A thick dot upon a șade ( $\dot{\mathbf{s}})$ usually indicates the Ar. dad, as in

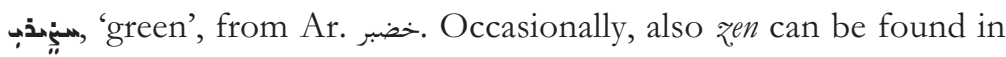
rendering a /ḍ/, as in sậ, 'damage, wrong', from Ar. ضرر due to the influence of Kurdish.

A thick dot upon a tet $(\underset{f}{)})$ usually indicates the Ar. $z a$, as in

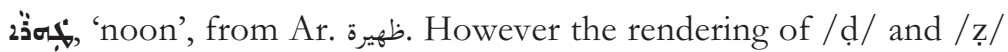
fluctuates, and they are often interchanged.

As seen from the above examples, the written record of an oral text can raise a number of methodological difficulties. Firstly an author has to adapt the traditional Syriac alphabet to a vernacular phonological system, which lacks of normalization and standard orthography. For this reason, the graphic rendering of the terms fluctuates to such an extent that the spelling varies not only from one manuscript to another, but also within a single manuscript. The

10 Odisho remarked that in Urmi [q] may shift into a voiceless unaspirated velar plosive $[\mathrm{k}]$, while in the koine it retains its original nature as a voiceless unaspirated uvular plosive. Odisho, The Sound System, 25. 
rendering can be very different from author to author because it often reflects the phonetic characteristics of a particular vernacular or, in rarer cases, some diachronic variations of a term.

In the $19^{\text {th }}$ and $20^{\text {th }}$ centuries, the manuscript tradition of the region of Alqosh produced a number of specimens, some of which reached Europe and became there a source of study for Western scholars. One of the most assiduous collectors of manuscripts was certainly the German philologist Eduard Sachau, who traveled the Middle East at the end of the 19th century and had copies made of a large number of Neo-Aramaic texts. His collections, now preserved in Berlin ${ }^{11}$ and London, ${ }^{12}$ laid the foundations for the study of the written Neo-Aramaic vernacular poetry in Europe. ${ }^{13}$

In the London collection, a bilingual manuscript (Or. 9321, ff. 537-621) contains a Sureth version of the Story of Ahiqar together with its translation into Arabic. This text was copied in Baghdad by the priest Gibrayl Quryaquza ${ }^{14}$ on Sachau's request at the end of the $19^{\text {th }}$ century. ${ }^{15}$ Some short excerpts of this tale are given here as an example of East Syriac literary text prose in the late manuscript tradition.

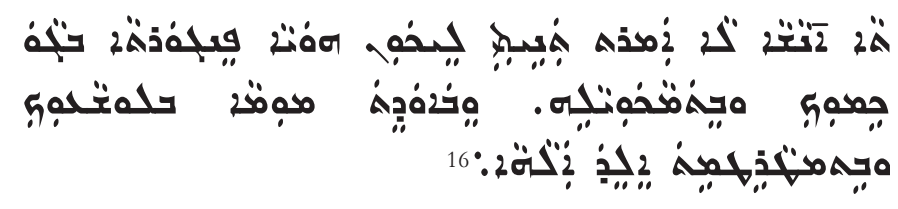

${ }^{11}$ Mark Lidzbarski, "Geschichte des weisen Achikâr", in Geschichten und Lieder aus den neuaramäischen Hand- schriften der königlichen Bibliothek ₹n Berlin, Beiträge zur Volks- und Völkerkunde (Weimar: Emil Felber 1896 [1 ${ }^{\text {st }}$ ed.], Hildesheim-New York: Georg Olms Verlag, 1973 [2 ${ }^{\text {nd }}$ ed.]), I, 1-77; II, 1-41.

12 Alessandro Mengozzi, "The Neo-Aramaic Manuscripts of the British Library: Notes on the Study of the Durikyatha as a Neo-Syriac Genre,"Le Muséon 112 (1999), 459-494.

${ }^{13}$ Among the first to study this subject were Mark Lizbarski, who published a selection of Sacahu's manuscripts in 1896; Vandenhoff, who translated in German some vernacular religious poems; and Sachau himself, who wrote a text on the Neo-Syriac poetry.

${ }^{14}$ Gibrayl Quryaquza, a native of Telkepe, moved to Baghdad at the age of fourteen and few years later entered the patriarchal seminary in Mosul where he took his vows in 1893. See LS 9321, ff. 697 and 701.

15 See LS 9321, f. 696.

${ }^{16}$ See LS 9321, ff. 545-546. 
Do not tell people about my advice, it might become as burning coals ${ }^{17}$ in your mouth and it will strike it, and you will blame your tongue and lament before God.

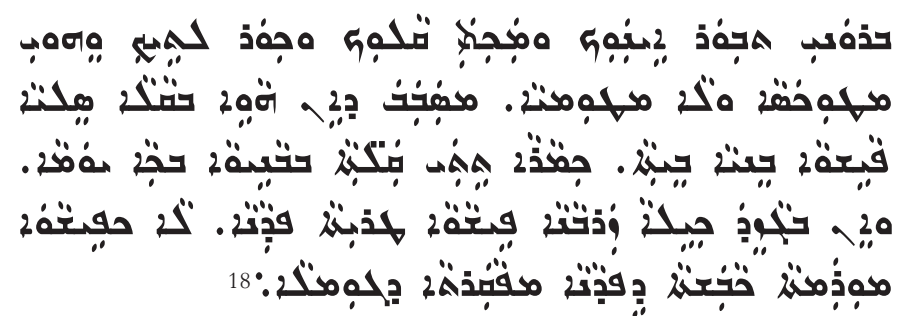

My son, turn away your eyes and lower your voice, keep your eyes down, be self-controlled and be not debauched because, were a house built by shouting a donkey would build two in a day, and if the plough were drawn by brute force, the yoke ${ }^{19}$ would never be lifted from the camel's neck.

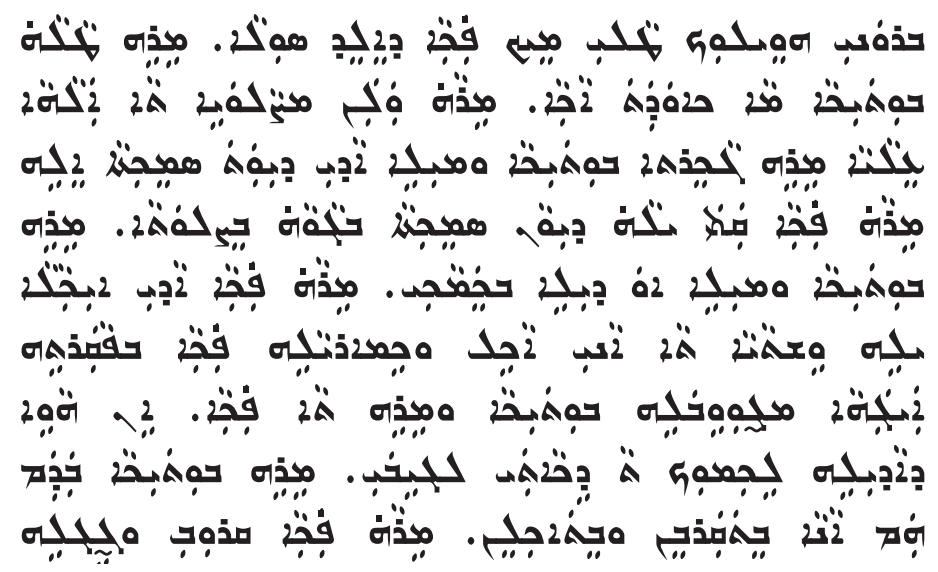

${ }^{17}$ The term used instead of 'burning coals' in the Sureth text is ILigion, pengorta (perhaps from Pers. بيّخرة, pangara, 'kettle') not used elsewhere with this meaning. The text is probably corrupt, to the extent that the Arabic translation gives: jamratan 'aw jadwata nārin, 'burning coals or firebrands'.

${ }^{18}$ See LS 9321, ff. 547-548.

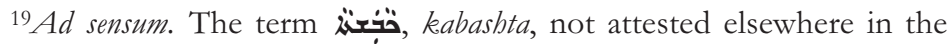
manuscript, could be related to the Ar. root kbs, 'to press, push', hence 'yoke'. 


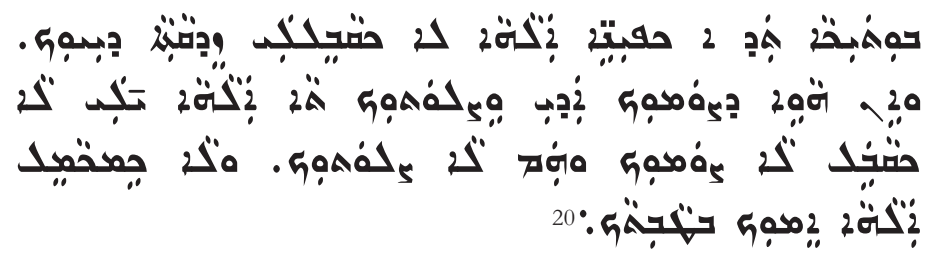

My son, to me you were as the snare ${ }^{21}$ on an a dunghill; a sparrow ${ }^{22}$ said to her: "What are you doing here?" She replied: "I am praying here God Almighty". Then the sparrow asked: "And what is this stuff you are placed on?". The snare replied: "It is the stick on which I lean when I pray". The sparrow asked: "And what is that thing in your mouth?" The snare replied: "It is the food and drink for those who come near me". The sparrow said: "So I will come near and eat too!" The snare said: "Come near!". The sparrow went up to eat and the snare caught him by his neck. Then the sparrow answered and said to the snare: "If this is your bread for the hungry, may God not accept your alms. And if these are your fasting and your prayer to God, may God accept neither your fasting nor your prayer and may God not perfect what is good concerning you".

\section{CONCLUSIONS}

This text exemplifies the salient features of the late Neo-Aramaic manuscript production in Northern Iraq. Authors and scribes appear to be usually cultured people with a knowledge of Classical Syriac writings. Gibrayl Quryaquza is no exception: his handwriting in Syriac letters is experienced and neat, although not elegant. The influence from Classical Syriac appears in his text from many orthographic factors. One of the most significant keys is a dot on the $\sigma$ in the feminine suffix (e.g. masculine and feminine suffixes. This etymological spelling of the suffixes is used also when attached to a preterit verbal tense, as in

${ }^{20}$ See LS 9321, ff. 613-614.

${ }^{21}$ Although the word paḥa, 'snare', is listed in Classical Syriac, the vernacular language uses the Arabic loan fahbh, as attested with a / $\underline{h}$ / instead of a / $/$ and a dot above the initial /p/ to mark the spirantized pronunciation of the letter.

${ }^{22}$ The term butika, 'sparrow', from Kurd. beytik, is attested (also in the form bedika) by Eleanor Coghill, "Four Versions of a Neo-Aramaic Children's Story," Aram 21 (2009), 255. 
مِدّت , 'she said', where the pronunciation was almost doubtless - $a$. Moreover, the linea occultans - a line placed above a consonant to prevent it from being pronounced - is constantly marked throughout the text. Linea occultans represents a means by which the author can significantly act both on the orthography and phonology of a word retaining its historical form (e.g. تَبْد its current pronunciation (e.g. ئك 'fox').

However, it is clear that a phonetic spelling is employed rather than a historical spelling, although impossible to tell when the changes in orthographical rendering result from deliberate choices of the writer or unconscious influence by the spoken languages of the region. The presence of Persian and Kurdish loanwords suggests that these languages were known to a certain extent. In the region of Mosul, Arabic was the most common language and the local dialect of Arabic was employed also by Christians. Literate Christians had a knowledge of Classical Syriac and written Arabic as well.

This complicated linguistic situation is well reflected in MS LS 9321, where a large amount of loanwords from a number of non-Aramaic languages shows a lively regional vocabulary to which the Neo-Aramaic dialects actively contributed.

\section{BIBLIOGRAPHY}

Braida, Emanuela. "A Hagiographical Tale: On the Hermit Barmalka by Joseph 'Abbaya of Alqosh", in Religious Poetry in Vernacular Syriac from Northern Iraq (17th-20th Centuries). An Anthology, Corpus Scriptorum Christianorum Orientalium 627 and 628, ed. A. Mengozzi (Leuven: Peeters, 2011), I, 95-108; II, 83-98.

Braida, Emanuela. "A Poetic Adaptation of Historical Sources: On an Attack by the Mongols at Karamlish by Thomas Hanna of Karamlish", in Religious Poetry in Vernacular Syriac from Northern Iraq (17th-20th Centuries). An Anthology, Corpus Scriptorum Christianorum Orientalium 627 and 628, ed. A. Mengozzi (Leuven: Peeters, 2011), I, 109-31; II, 99-119.

Braida, Emanuela. "A Story of Ahiqar in Neo-Aramaic according to MS London Sachau 9321." The Journal of the Canadian Society for Syriac Studies 14 (2014), forthcoming.

Coghill, Eleanor. "Four Versions of a Neo-Aramaic Children's Story." Aram 21 (2009): 251-280. 
Lidzbarski, Mark. "Geschichte des weisen Achikâr", in Geschichten und Lieder aus den neuaramäischen Handschriften der königlichen Bibliothek zu Berlin, Beiträge zur Volks- und Völkerkunde (Weimar: Emil Felber 1896 [1 ${ }^{\text {st }}$ ed.], Hildesheim-New York: Georg Olms Verlag, 1973 [2nd ed.]), I, 1-77; II, 1-41.

Maclean, Arthur J. Grammar of the dialects of vernacular Syriac: as spoken by the Eastern Syrians of Kurdistan, north-west Persia, and the Plain of Mosul: with notices of the vernacular of the Jews of Azerbaijan and of Zakhu near Mosul (London: Cambridge University Press), 1895

Maclean, Arthur J. A Dictionary of the Dialects of Vernacular Syriac: As Spoken by the Eastern Syrians of Kurdistan, North West Persia and the Plain of Mosul (Oxford: Clarendon), 1901.

Macuch, Rudolf. Geschichte der spät- und neusyrischen Literatur (Berlin: Gruyter, 1976).

Mar Emmanuel J., Emmanuel. "A Durektha on the "Battle of Urmia." The Journal of the Canadian Society for Syriac Studies, 11 (2011): 34-44.

Mengozzi, Alessandro. "The Neo-Aramaic Manuscripts of the British Library: Notes on the Study of the Durikyatha as a Neo-Syriac Genre.” Le Muséon 112 (1999): 459-494.

Mengozzi, Alessandro. Israel of Alqosh and Joseph of Telkepe: A Story in a Truthful Language (Leuven: Peeters 2002)

Mengozzi, Alessandro and Mustafa Dehqan. "A Kurdish Garshuni Poem by David of Barazne (19th century)." Hugoye: Journal of Syriac Studies 17:1 (2014): 53-79.

Muḥattas, Rubeyl. Kunnāšà d-taśitā w-matlè d-'Ahiqar hakkimā 'am mèmrā d-Ploțarqos w-meddem meddem men Pardaysā d-'abāhätā, Trichur 1941 (1961, 2a ed.).

Murre-van den Berg, Hendrika L. From a Spoken to a Written Language: The Introduction and Development of Literary Urmia Aramaic in the Nineteenth Century (Leiden: Publication of the De Goeje Fund, 1999).

Nau, François. "Documents relatifs à Ahikar." Revue de l'Orient Chrétien 21:3 (1918-1919) : 261-284.

Odisho, Edward. The Sound System of Modern Assyrian (Wiesbaden: Harrassowitz, 1988). 
Pennacchietti, Fabrizio A. Il Ladrone e il Cherubino: Dramma Liturgico Cristiano Orientale in Siriaco e Neoaramaico (Torino: Silvio Zamorani Editore, 1993).

Pennacchietti, Fabrizio A. "Zmiryata-d Rawe. Stornelli degli Aramei Kurdistani”, in Scritti in Onore di Giuliano Bonfante (Brescia: Paideia), 1976.

Sachau, Eduard. Verzeichnis der syrischen Handschriften der Königlichen Bibliothek zu Berlin, I (Berlin: Asher, 1899).

Sachau, Eduard. Skizze des Fellichi-Dialekts von Mosul (Berlin: Philosophische und historische Abhandlungen der Königlichen Akademie der Wissenschaften zu Berlin, 1895).

Vandenhoff, Bernard. "Vier geistliche Gedichte in syrischer und neusyrischer Sprache aus den Berliner Handschriften Sachau 188 and 223 übersetzt und mit Einleitung versehen." OC 8 (1908): 389-452. 
